\title{
HUBUNGAN TINGKAT PENGETAHUAN DAN SIKAP REMAJA PUTRI TENTANG SADARI DENGAN PERILAKU SADARI DI SMAN 1 KAWALI 2017
}

\author{
Selvi Nur Azizah \\ Selvi.mvi.kaka@gmail.com
}

\section{A. ABSTRAK}

Pemeriksaan payudara sendiri (Sadari) merupakan salah satu langkah deteksi dini untuk menemukan kanker payudara stadium awal yang akan lebih efektif jika dilakukan sedini mungkin. Pengetahuan, sikap, dan perilaku remaja putri tentang Sadari sangat penting untuk diketahui. Penelitian ini bertujuan untuk mengetahui hubungan antara tingkat pengetahuan dan sikap remaja putri tentang Sadari dengan perilaku Sadari di SMAN 1 Kawali 2017.

Jenis penelitian ini merupakan penelitian analitik dengan pendekatan cross sectional. Populasi dalam penelitian ini adalah seluruh remaja putri SMAN 1 Kawali di Kecamatan Kawali Kabupaten Ciamis tahun 2017 sebanyak 682 orang. Ukuran sampel yang digunakan dalam penelitian ini sebanyak 88 orang dengan cara pengambilan sampel menggunakan rumus Slovin. Instrumen penelitian menggunakan angket dengan skala Guttman. Uji hipotesis menggunakan uji chi square.

Hasil penelitian didapatkan bahwa 70,5\% remaja putri memiliki tingkat pengetahuan Sadari yang baik, 22,7\% remaja putri memiliki tingkat pengetahuan yang cukup sedangkan 6,8\% memiliki tingkat pengetahuan yang kurang. Sikap remaja putri terhadap Sadari 44,3\% tergolong positif dan sebanyak 55,7\% tergolong negatif. Perilaku Sadari remaja putri 55,7\% tergolong positif dan 44,3\% tergolong negatif. Terdapat hubungan antara tingkat pengetahuan remaja putri tentang Sadari dengan perilaku Sadari di SMAN 1 Kawali 2017 dengan nilai signifikasi 0,001 < 0,05. Tidak terdapat hubungan antara sikap remaja putri tentang Sadari dengan perilaku sadari di SMAN 1 Kawali 2017 dengan nilai signifikansi 0,324 > 0,05 .

SMAN 1 Kawali diharapkan dapat lebih meningkatkan tindakan promotif secara rutin dengan melakukan pencegahan kanker payudara dengan Sadari kepada remaja putri SMAN 1 Kawali.

Kata Kunci : pengetahuan, sikap, perilaku, Sadari

\section{B. PENDAHULUAN}

Kanker adalah penyakit tidak menular yang ditandai dengan pertumbuhan sel tidak normal/terus menerus dan tidak terkendali yang dapat merusak jaringan sekitarnya serta dapat menjalar ke tempat yang jauh dari asalnya yang disebut metastasis. Data dari International Agency Research on Cancer (IARC) terdapat 14.067.894 kasus kanker dan 8.201.575 kematian akibat kanker di seluruh dunia. Kanker payudara, kanker prostat, dan kanker paru merupakan jenis kanker dengan presentasi tertinggi yaitu 43,3\%, 30,7\% dan 23,1\% (Globocan, 2008). Insidens kanker di Indonesia masih belum diketahui secara pasti, karena belum ada registrasi kanker berbasis populasi yang dilaksanakan (Kemenkes RI, 2010).

Pada tahun 2008 estimasi insidens kanker payudara di Indonesia sebesar 36 per 100.000 perempuan (Globocan, 2008). Berdasarkan data Riset Kesehatan Dasar tahun 2013, prevalansi kanker payudara di Indonesia mencapai 0,5 per 1000 perempuan (Kemenkes RI, 2015). 
Riset yang dilakukan oleh Badan Penelitian dan Pengembangan Kesehatan Kemenkes RI tahun 2013, estimasi jumlah penderita kanker servik dan kanker payudara di Indonesia pada tahun 2013 bahwa provinsi Jawa Timur, Jawa Tengah, dan Jawa Barat memiliki estimasi jumlah penderita kanker servik dan kanker payudara terbesar. Adapun jumlah kasus kanker payudara di Jawa Barat pada tahun 2013 sebanyak 6.701 (Kemenkes RI, 2015).

Survei yang dilakukan Yayasan Kanker Payudara Jakarta pada tahun 2005 menunjukkan $80 \%$ masyarakat tidak mengerti pentingnya pemeriksaan dini payudara. Sebanyak 70\% kasus kanker payudara ditemukan dalam stadium lanjut sehingga angka kesintasannya rendah. Hal ini dikarenakan masih rendahnya kesadaran, pengertian, dan pengetahuan masyarakat tentang kanker payudara, sementara penanganan kanker payudara secara lintas sektoral belum mendapat prioritas dari pemerintah (Rasjidi, 2010).

Pemeriksaan payudara sendiri (Sadari) merupakan salah satu langkah deteksi dini untuk menemukan kanker payudara stadium awal yang akan lebih efektif jika dilakukan sedini mungkin, sebab $85 \%$ kelainan di payudara justru pertama kali dikenali oleh penderita bila tidak dilakukan penapisan secara massal (Rasjidi, 2010).

Adapun faktor-faktor yang menyebabkan kelambatan deteksi dini diantaranya penderita tidak mengetahui tentang kanker payudara, kurang memperhatikan payudara, rasa takut akan operasi, faktor ekonomi dan rasa malu memperlihatkan payudara. Padahal penemuan payudara sedini mungkin yang didiagnosa secara benar dan diobati dengan optimal akan menambah harapan hidup dan kesembuhan (Luwia, 2003).

Masalah lainnya dalam penanggulangan kanker payudara adalah rendahnya pengetahuan masyarakat tentang kanker payudara. Penyebaran informasi mengenai faktor resiko kanker payudara dan pemeriksaan dini payudara mungkin kurang tersebar di masyarakat. Masih banyak wanita yang belum menyadari pentingnya melakukan deteksi dini.

Penelitian akan dilakukan di wilayah kabupaten Ciamis dengan alasan penderita kanker di wilayah tersebut tergolong besar. Berdasarkan hasil studi pendahuluan di Yayasan Kanker Indonesia (YKI) kabupaten Ciamis dapat diketahui yang mengidap kanker payudara pada tahun 2014 sampai 2015 sebanyak 39 orang. YKI sudah melakukan sosialisasi terkait penyakit kanker payudara ke beberapa sekolah SMA/SMK di Kabupaten Ciamis pada tahun 2015 yang diwakili 5 siswa dari setiap sekolahnya. Sosialisasi akan dilaksanakan kembali pada tahun 2016. Sasaran yang mendapat sosialisasi adalah para remaja karena kanker harus dicegah sejak usia remaja. Pada tahun 2017 YKI tidak mengadakan sosialisasi mengenai kanker payudara terhadap remaja. Sehingga perlu diketahui tingkat pengetahuan dan sikap tentang Sadari di wilayah kabupaten Ciamis.

Berdasarkan data tahun 2015/2016 per 1 Juni 2016 terdapat 17 Sekolah Menengah Atas Negeri (SMAN) di Kabupaten Ciamis, diantaranya SMAN 1 Kawali yang memiliki siswa perempuan terbanyak se-kabupaten Ciamis yaitu 682 siswi. Dari hasil wawancara yang dilakukan ke pihak SMAN 1 Kawali, sekolah ini pernah mendapatkan sosialisasi mengenai deteksi dini kanker payudara dengan melakukan Sadari.

Berdasarkan uraian di atas, penulis berminat untuk melakukan penelitian di SMAN 1 Kawali kabupaten Ciamis dengan judul "Hubungan Tingkat Pengetahuan dan Sikap Remaja Putri tentang Sadari dengan Perilaku Sadari di SMAN 1 Kawali 2017'. Sehingga 
diharapkan dengan pengetahuan yang baik, terutama bagi usia remaja bisa melakukan pencegahan dan deteksi dini kanker payudara dengan pemeriksaan payudara sendiri (Sadari).

\section{METODOLOGI PENELITIAN}

\section{Rancangan Penelitian}

Rancangan penelitian yang digunakan dalam penelitian ini adalah penelitian analitik dengan pendekatan penelitian crossectional

\section{Waktu dan Tempat Penelitian}

Pengumpulan data telah dilakukan pada Rabu, 8 Februari 2017. Penelitian dilakukan di SMAN 1 Kawali, Kecamatan Kawali, Kabupaten Ciamis.

\section{Subjek Penelitian}

Populasi dalam penelitian ini adalah seluruh remaja putri siswa SMAN 1 Kawali Kabupaten Ciamis Tahun Pelajaran 2016/2017 sebanyak 682 orang. Cara pengambilan sampel dalam penelitian ini adalah sampling kuota, yaitu teknik untuk menentukan sampel dari populasi yang mempunyai ciri-ciri tertentu sampai jumlah kuota yang diinginkan. Ciri-ciri tertentu dalam penelitian ini yakni peserta didik berjenis kelamin perempuan di SMAN 1 Kawali Kabupaten Ciamis yang berjumlah 88 orang

\section{Variabel Penelitian}

Variabel independen dari penelitian ini adalah pengetahuan dan sikap remaja, dan variabel dependen adalah perilaku Sadari.

\section{Instrumen Penelitian}

Instrumen penelitian yang digunakan dalam penelitian ini adalah angket yang dibuat sendiri oleh peneliti. Jumlah masing-masing angket sebanyak 18 soal untuk variabel pengetahuan dan sikap, dan 17 soal untuk variabel perilaku sadari.

\section{Analisa Data}

Analisis data yang digunakan dalam penelitian ini adalah analisis Bivariat, analisis bivariat adalah analisa yang dilakukan pada dua variabel yang diduga berhubungan atau berkorelasi (Notoatmodjo, 2010). Rumus yang digunakan adalah chi square dengan batas kemaknaan $\sigma=0,05$

\section{PEMBAHASAN}

\section{Hasil Penelitian}

a. Karakteristik Responden

Jumlah responden yang menjadi objek dalam penelitian ini sebanyak 88 orang remaja putri usia 15 sampai 18 tahun. Karakteristik responden dapat diketahui dari angket biodata yang diisi responden.Berikut disajikan karakteristik responden berdasarkan usia.

Tabel 1

Karakteristik Responden Berdasarkan Usia

\begin{tabular}{|c|c|c|}
\hline $\begin{array}{c}\text { Usia } \\
\text { (tahun) }\end{array}$ & Jumlah & Persentase \\
\hline 15 & 14 & $15,9 \%$ \\
\hline 16 & 43 & $48,9 \%$ \\
\hline 17 & 30 & $34,1 \%$ \\
\hline 18 & 1 & $1,1 \%$ \\
\hline Jumlah & $\mathbf{8 8}$ & $\mathbf{1 0 0 \%}$ \\
\hline
\end{tabular}


b. Analisis Univariat

1) Tingkat Pengetahuan Tentang Sadari

Tabel 2

Hasil Ukur Variabel

Tingkat Pengetahuan tentang Sadari

\begin{tabular}{|l|c|c|}
\hline Kategori & Frekuensi & Persen \\
\hline Baik & 62 & $70,5 \%$ \\
\hline Cukup & 20 & $22,7 \%$ \\
\hline Kurang & 6 & $6,8 \%$ \\
\hline Total & $\mathbf{8 8}$ & $\mathbf{1 0 0 \%}$ \\
\hline
\end{tabular}

Berdasarkan data di atas, diketahui bahwa tingkat pengetahuan remaja putri tentang Sadari di SMA Negeri 1 Kawali 2017 dari 88 orang terdapat 62 orang $(70,5 \%)$ termasuk kategori baik

2) Sikap Terhadap Sadari

Tabel 3

Hasil Ukur Sikap tentang Sadari

\begin{tabular}{|c|c|c|}
\hline Kategori & Frekuensi & Persen \\
\hline Positif & 39 & $44,3 \%$ \\
\hline Negatif & 49 & $55,7 \%$ \\
\hline Total & $\mathbf{8 8}$ & $\mathbf{1 0 0} \%$ \\
\hline
\end{tabular}

Diketahui bahwa remaja putri yang mempunyai sikap positif terhadap Sadari di SMA Negeri 1 Kawali dari 88 orang, terdapat 49 orang $(55,7, \%)$.

3) Perilaku Sadari

Tabel 4

Hasil Ukur Variabel Perilaku Sadari

\begin{tabular}{|c|c|c|}
\hline Kategori & Frekuensi & Persen \\
\hline Positif & 49 & $55,7 \%$ \\
\hline Negatif & 39 & $44,3 \%$ \\
\hline Total & $\mathbf{8 8}$ & $\mathbf{1 0 0} \%$ \\
\hline
\end{tabular}

Diketahui bahwa remaja putri di SMA Negeri 1 Kawali yang mempunyai perilaku positif terhadap Sadari sebanyak 49 orang $(55,7 \%)$.

c. Analisis Bivariat

1) Analisis HubunganTingkat Pengetahuan Remaja Putri dengan perilaku Sadari

Tabel 5

Hasil Uji Fisher Exact Hubungan Tingkat Pengetahuan Remaja Putri Tentang Sadari dengan Perilaku Sadari

\begin{tabular}{|c|c|c|}
\hline Variabel & $\begin{array}{c}\text { Korelasi } \\
\text { Fisher } \\
\text { Exact }\end{array}$ & $\begin{array}{c}\boldsymbol{P} \text { - } \\
\text { Value* }\end{array}$ \\
\hline $\begin{array}{c}\text { Tingkat } \\
\text { Pengetahuan } \\
\text { dan Perilaku }\end{array}$ & 12,388 & 0,001 \\
\hline
\end{tabular}

Berdasarkan tabel hasil uji Fisher Exact di atas dapat diketahui bahwa nilai korelasi Fisher Exact $=12,388$ dan $p$-value atau Sig 0,001, karena $p$ value lebih kecil dari $\alpha 0,05$ maka $\mathrm{H}_{\mathrm{a}}$ diterima. Artinya terdapat hubungan antara tingkat pengetahuan remaja putri tentang Sadari dengan Perilaku Sadari di SMAN 1 Kawali.

2) Analisis HubunganTingkat Pengetahuan Remaja Putri dengan perilaku Sadari

Tabel 6

Hasil Uji Chi Square $\left(\chi^{2}\right)$ Hubungan Sikap Remaja Putri tentang Sadari dengan Perilaku Sadari

\begin{tabular}{|c|c|c|}
\hline Variabel & $\begin{array}{c}\text { Korelasi } \\
\text { Chi Square } \\
\left(\boldsymbol{\chi}^{\mathbf{2}}\right)\end{array}$ & $\begin{array}{c}\boldsymbol{P} \text { - } \\
\text { Value }^{*}\end{array}$ \\
\hline $\begin{array}{c}\text { Sikap dan } \\
\text { Perilaku }\end{array}$ & 0,974 & 0,324 \\
\hline
\end{tabular}


Berdasarkan tabel hasil uji Chi Square di atas dapat diketahui bahwa nilai Pearson Chi Square $\left(\chi^{2}\right)=0,974$ dan $p$-value atau Sig 0,324, karena $p$ value lebih besar dari $\alpha 0,05$ maka $\mathrm{H}_{\mathrm{a}}$ ditolak. Artinya tidak terdapat hubungan antara sikap remaja putri tentang Sadari dengan Perilaku Sadari di SMAN 1 Kawali.

\section{E. PEMBAHASAN}

Hasil analisis data menunjukkan terdapat hubungan antara tingkat pengetahuan remaja putri tentang Sadari dengan Perilaku Sadari, tetapi tidak terdapat hubungan antara sikap remaja putri tentang Sadari dengan perilaku Sadari di SMAN 1 Kawali.

$\begin{array}{lrr}\text { Hasil } & \text { penelitian } & \text { tersebut } \\ \text { membuktikan } & \text { bahwa } & \text { tingkat } \\ \text { pengetahuan } & \text { tentang } & \text { Sadari } \\ \text { berhubungan } & \text { erat dengan } & \text { perilaku }\end{array}$
Sadari. Sejalan dengan teori Snehandu B. Karr dalam Azwar (2011) bahwa "Ada atau tidaknya informasi tentang kesehatan, seseorang akan cenderung mengikuti suatu tindakan apabila ia mempunyai penjelasan yang lengkap tentang tindakan yang akan dilakukannya tersebut." Sebagaimana diuraikan di awal, bahwa remaja putri di SMAN 1 Kawali telah banyak menerima informasi tentang kesehatan payudara melalui sosialisasi tentang Sadari. Informasi yang telah mereka terima telah menjadi pengetahuan dalam ingatan mereka yang mendorong mereka untuk melaksanakan Sadari.

Perilaku tentang Sadari tidak tergantung pada sikap remaja putri di SMAN 1 Kawali. Hal ini sejalan dengan pendapat Newcomb, et. al.(1985) bahwa "Sikap merupakan kesiapan atau kesediaan untuk bertindak, dan bukan merupakan pelaksanaan motif tertentu". Sehingga berdasarkan pengertian diatas, sikap bersifat tertutup dan merupakan predisposisi perilaku seseorang terhadap suatu stimulus. Jadi, sikap seseorang kemungkinan menimbulkan perilaku atau tidak.

Penelitian ini sejalan dengan hasil penelian yang dilakukan oleh Dinnia Hanivah Novasari, dkk (2016), yakni (1) Ada hubungan pengetahuan dengan praktik pemeriksaan payudara sendiri (Sadari), dan (2) Tidak ada hubungan sikap dengan praktik pemeriksaan payudara sendiri (Sadari).

Mengamati konsep dari Lawrence Green bahwa perilaku dipengaruhi oleh tiga faktor yaitu :

a. Faktor predisposisi, faktor faktor ini mencakup tentang pengetahuan dan sikap seseorang terhadap sebuah rangsangan atau stimulus yang ia dapatkan.

b. Faktor pemungkin, faktor faktor ini mencakup ketersedian sarana dan prasarana atau fasilitas sebagai penunjang terjadinya sebuah perilaku yang terjadi pada seseorang tersebut.

c. Faktor penguat, faktor-faktor penguat ini meliputi faktor sikap dan perilaku tokoh masyarakat, tokoh agama, sikap dan perilaku dari peran role dari seseorang yang membuatnya menirukan apa yang mereka lakukan semuanya (Notoatmodjo, 2007).

Konsep di atas menjelaskan bahwa pengetahuan dan sikap merupakan sebagian kecil faktor yang dapat mempengaruhi perilaku remaja putri, faktor-faktor lain kemungkinan belum menyentuh mereka. Ketersediaan sarana prasarana untuk mendapatkan pengetahuan lebih tentang Sadari mungkin tidak dimiliki sebagian remaja putri. Kemungkinan lain, bahwa faktor penguat perilaku seperti orang tua dan tenaga kesehatan belum menguatkan perilaku mereka. 


\section{F. KESIMPULAN DAN SARAN}

\section{Kesimpulan}

a. Data tingkat pengetahuan remaja putri tentang Sadari di SMAN 1 Kawali 2017 yaitu 62 orang mempunyai tingkat pengetahuan Sadari baik, 20 orang mempunyai tingkat pengetahuan Sadari cukup dan 6 orang mempunyai tingkat pengetahuan Sadari kurang.

b. Data sikap remaja putri tentang Sadari di SMAN 1 Kawali 2017 yaitu 39 orang mempunyai sikap Sadari positif dan 49 orang mempunyai sikap Sadari negatif.

c. Data perilaku Sadari remaja Putri di SMAN 1 Kawali 2017 yaitu 49 orang mempunyai perilaku positif dan 39 orang mempunyai perilaku negatif.

d. Terdapat hubungan antara tingkat pengetahuan remaja putri tentang

\section{G. DAFTAR PUSTAKA}

Ali, M. (2009). Psikologi Remaja (Perkembangan Peserta Didik), Bumi Aksara, Jakarta.

Arikunto, S. (2010). Prosedur penelitian : Suatu Pendekatan Praktik, ed. Revisi, Rineka Cipta, Jakarta..

Azwar, S. (2011). Sikap dan Perilaku: Sikap Manusia Teori dan. Pengukurannya, 2 nd ed, Pustaka Pelajar, Yogyakarta.

Bustan, M. (2007). Epidemiologi Penyakit Tidak Menular, Rineka Cipta, Jakarta.

Corwin. (2009). Buku Saku Patofisiologi Corwin, Aditya Media Gandahusada, Jakarta.

Novasari, dkk. (2016). Hubungan Pengetahuan, Sikap dan Paparan Media Informasi dengan Praktik Pemeriksaan Payudara Sendiri (SADARI) pada Santriwati Pondok
Sadari dengan perilaku Sadari di SMAN 1 Kawali dengan nilai Sig $0,001<\alpha 0,05$.

e.Tidak terdapat hubungan antara sikap remaja putri tentang Sadari dengan Perilaku Sadari di SMAN 1 Kawali dengan nilai Sig $0,324>\alpha 0,05$.

\section{Saran}

Diharapkan bagi siswi SMAN 1 Kawali dapat lebih meningkatkan perhatian terhadap pendidikan kesehatan khususnya tindakan promotif secara rutin dengan melakukan sosialisasi pencegahan kanker payudara dengan Sadari kepada remaja putri SMAN 1 Kawali. Petugas kesehatan Diharapkan tenaga kesehatan khususnya bidan terus menyelenggarakan kegiatan sosialisasi Sadari dengan bekerja sama dengan pihak-pihak terkait agar pengetahuan dan sikap tentang Sadari lebih meningkat.
Pesantren Al-Ishlah Tembalang

Semarang Tahun 2016, Jurnal

Kesehatan Masyarakat (e-Journal), Vol. 4, No. 4.

Depkes RI. (2009). Sistem Kesehatan Nasional, Jakarta.

Depkes RI. (2015). Implementasi Jaminan Kesehatan Nasional (JKN), Jakarta.

Fitriani, S. (2011).Promosi Kesehatan, Graha Ilmu, Yogyakarta.

Globocan. (2008). Cancer Incidence and Mortality. Tersedia dalam: http://globocan.iarc, diakses pada tanggal 1 September 2016.

Iqbal, H. (2002). Pokok - pokok Materi Metodologi Penelitian dan Aplikasinya, Ghalia Indonesia, Jakarta.

Kemenkes RI. (2010). Rencana Strategis Kementerian Kesehatan, Jakarta. 
Kemenkes RI. (2014). Laporan Nasional Riset Kesehatan Dasar, Pusat penelitian pengembangan kesehatan, Jakarta.

Kemenkes RI. (2015). Buletin Jendela Data dan Informasi Kesehatan, Semester 1, Jakarta.

Kemenkes RI. (2010). Kepmenkes RI Nomor 796/Menkes/SK/VII/2010 Tentang Pedoman Tekhnis Pengendalian Kanker Payudara dan Kanker Leher Rahim, Jakarta.

Lenggogeni. (2011). Faktor-faktor yang Berhubungan Dengan Tindakan Deteksi Dini Kanker Payudara Melalui Pemeriksaan Payudara Sendiri Oleh Mahasiswi Jalur A Program Studi Ilmu Kesehatan Masyarakat Fakultas Kedokteran Unand Padang Tahun 2011, Universitas Andalas Padang, Padang.

Monks and Knoers. (2010). Psikologi Perkembangan Pengantar dalam berbagai bagiannya, Gadjah Mada, Yogyakarta.

Mulyani. (2013). Kanker Payudara dan PMS Dalam Kehamilan, Nuha Medica, Yogyakarta.

Nisman. (2011). Lima Menit Kenali Payudara, C.V Andi, Yogyakarta.

Notoatmodjo. (2007). Promosi Kesehatan dan Ilmu Perilaku, Rineka Cipta, Jakarta

Notoatmodjo. (2010).Metodologi Penelitian Kesehatan, Rineka Cipta, Jakarta.

Nursalam. (2008).Konsep dan Penerapan Metodologi Penelitian Ilmu Keperawatan, Salemba Medika, Jakarta.

Olfah, dkk. (2013). Kanker Payudara dan Sadari, Nuha Medika, Yogyakarta.

Prasetyo. (2007). Metodologi Penelitian Kuantitatif Teori dan Aplikasinya, Rajawali Pers, Jakarta.
Rasjidi, I. (2010). Deteksi Dini \& Pencegahan Kanker pada Wanita, Sagung Seto, Jakarta.

Romauli. (2009). Kesehatan Reproduksi, Nuha Medika, Yogyakarta.

Sarwono, S. (2004). Psikologi Remaja, Ed. revisi 8. Raja Grafindo Pustaka, Jakarta.

Setiati, E. (2009). Waspadai 4 Kanker Ganas Pembunuh Wanita : Kanker Rahim, Kanker Indung Telur, Kanker Leher Rahim, Kanker Payudara, Ed. 1, Andi, Jakarta.

Staf Pengajar FKUI. (2008). Patologi Tumor Ganas Payudara, Kursus Singkat Deteksi Dini dan Pencagahan Kanker, FKUI-POI, Jakarta.

Sugiyono. (2009). Metode Penelitian Kuantitatif, Kualitatif dan $R \& D$, Alfabeta, Bandung.

Tambunan. (1993). Patologi Gastroenterologi, Penerbit Buku Kedokteran (EGC), Jakarta.

Walgito. (2008).Pengantar Psikologi Umum. Ed. 3, Adi, Yogyakarta.

Wawan, A and Dewi, M. (2010). Teori dan Pengukuran Pengetahuan, Sikap dan Perilaku Manusia, Nuha Medika, Yogyakarta.

WHO.(2013).Breast Cancer : Prevention and Control, Tersedia dalam: http://who.int, diakses pada tanggal 1 September 2016.

Widyastuti. (2009). Kesehatan Reproduksi, Fitra Maya, Yogyakarta. 